\title{
PENGEMBANGAN PERTUNJUKKAN CALUNG SEBAGAI MEDIA KOMUNIKASI DI ERA KONVERGENSI
}

\author{
C.Suprapti Dwi Takariani \\ Balai Pengkajian dan Pengembangan Komunikasi dan Informatika Bandung (BPPKI) Bandung, J1.Pajajaran No.88 \\ Bandung-40173, Jawa Barat, Telp.022-6017493,Fax.022-6021740. HP.081220179515. Email: \\ dwi.takariani@gmail.com \\ Naskah diterima tanggal 24 September 2014, direvisi tanggal 23 Oktober 2014, disetujui tanggal 26 November 2014
}

\section{DEVELOPMENT CALUNG PITALOKA SHOWS AS A MEDIA COMMUNICATIONS IN THE ERA OF CONVERGENCE}

\begin{abstract}
The development of information and communication technology (ICT) now is unstoppable. This condition had impacted the calung show development, due to people's appreciation has shifted and tend to like popular culture which is introduced by ICT products than the calung show. The issue in this study is how the development of the performing group calung Pitaloka as a medium of communication in the era of convergence. The purpose of this study is to analyze the strengths, weaknesses, opportunities, and threats, develop strategies, and formulation development of Pitaloka the group of calung show as a communication medium in the era of convergence. This study used a qualitative method with a case study approach. In this study determination of informants is using purposive sampling technique. The results showed that based on the conditions of Pitaloka the group of calung show currently they have more weaknesses than strengths, but they still have a chance even though the treat still exist from the outside, therefore the strategy could be implemented is to utilize the existing facilities and utilize the support and good cooperation with all parties.
\end{abstract}

Keywords: development, calung Pitaloka performing group, communication media.

\begin{abstract}
Abstrak
Perkembangan teknologi komunikasi dan informasi (TIK) saat ini sudah tidak terbendung lagi. Hal tersebut telah berdampak pada perkembangan pertunjukkan calung, karena apresiasi masyarakat terhadap pertunjukkan calung mulai bergeser dan cenderung menyukai budaya populer yang diperkenalkan melalui produk-produk TIK. Permasalahan dalam penelitian ini adalah bagaimana pengembangan grup pertunjukkan Calung Pitaloka sebagai media komunikasi di era konvergensi. Tujuan penelitian ini adalah ingin menganalisis kekuatan, kelemahan, peluang, dan ancaman, menyusun strategi, serta formulasi pengembangan grup pertunjukkan Calung Pitaloka sebagai media komunikasi di era konvergensi. Penelitian ini menggunakan metode kualitatif dengan pendekatan studi kasus. Dalam penelitian ini informan ditentukan dengan menggunakan teknik purposif sampling. Hasil penelitian menunjukkan berdasarkan kondisi grup pertunjukkan Calung Pitaloka saat ini lebih banyak kelemahan internal dibanding dengan kekuatannya, namun masih memiliki peluang meskipun tetap ada acaman dari luar, oleh karena itu strategi yang dapat dilaksanakan adalah memanfaatkan fasilitas yang ada dan menfaatkan dukungan serta menjalin kerjasama yang baik dengan berbagai pihak.
\end{abstract}

Kata kunci: pengembangan, grup pertunjukkan Calung Pitaloka, media komunikasi. 


\section{PENDAHULUAN}

Kesepakatan wakil dari negara-negara dunia termasuk Indonesia, yang mengikuti Konverensi Tingkat Tinggi Dunia tentang Masyarakat Informasi / World Summit On The Information Society (WSIS) di Jenewa tahun 2003 dan Tunisia tahun 2005, yang memunyai visi mewujudkan masyarakat informasi dan menghilangkan kesenjangan digital. Sementara di Indonesia visi Masyarakat Informasi Indonesia (MII) harus tercapai pada tahun 2015. Konsekuensi dari kesepakatan tersebut adalah menjadikan informasi bersifat bordeless di mana informasi bisa diakses siapapun, di manapun, tidak terbatas ruang dan waktu, di samping itu juga untuk mewujudkan masyarakat informasi dan diutamakan bagi masyarakat perdesaan.

Untuk memenuhi komitmen tersebut pemerintah Indonesia melakukan berbagai upaya, salah satunya adalah dengan membangun berbagai infrastruktur hingga ke pelosok tanah air. Hal tersebut dilakukan agar pesan-pesan atau informasi dapat dinikmati oleh seluruh masyarakat Indonesia sehingga diperlukan sebuah media yang bisa mendiseminasikan informasi hingga ke seluruh pelosok tanah air dan menjangkau masyarakat yang tinggal di daerah perdesaan.

Pemerintah melalui Kementerian

Komunikasi dan Informatika mengeluarkan sebuah regulasi yakni Peraturan Menteri Kominfo RI No: 17/PER/M.KOMINFO/03/2009 tentang

Diseminasi Informasi Nasional dan Peraturan Menteri Kominfo RI No: 08/PER/M.KOMINFO/6/2010 tentang Pedoman Pengembangan Pemberdayaan Lembaga Komunikasi Sosial. Kedua peraturan tersebut mengatur mengenai perlunya pemerintah baik pusat maupun daerah untuk melakukan diseminasi melalui media baik media elektronik maupun media lainnya, serta pengembangan dan pemberdayaan lembaga komunikasi sosial yang ada di daerah, salah satunya adalah pertunjukkan rakyat. Melalui pertunjukkan rakyat, diharapkan proses penyebaran informasi dapat menjangkau masyarakat hingga ke pelosok tanah air dan menjangkau daerah-daerah yang belum atau tidak terjangkau media massa.

Beberapa pertunjukkan rakyat bisa dikategorikan sebagai media tradisional dan dijadikan sebagai media komunikasi. Media tradisional tersebut berkembang pesat di Indonesia era tahun 70-an. Pada saat itu pemanfaatan pertunjukkan rakyat sebagai media komunikasi untuk menyampaikan informasi publik cukup efektif, karena selain memberikan hiburan, secara tidak langsung disampaikan pula pesan-pesan pembangunan, sehingga khalayak merasa sedang tidak diberikan ceramah. Seperti yang dikatakan oleh Suprawoto bahwa pertunjukkan rakyat yang berbasis kearifan lokal terasa lebih mengena di hati masyarakat. Sehingga menjadi media yang cukup efektif menyampaikan pesan kepada masyarakat. Seni pertunjukkan rakyat identik dengan media pertunjukkan rakyat (MPR) yang menggunakan kesenian rakyat sebagai media penyampai informasi secara timbal balik (komunikasi dua arah) yang dinilai efektif dan komunikatif. Dengan kata lain, "MPR" merupakan bentuk komunikasi yang menggunakan kesenian rakyat sebagai media (saluran informasi) (Suprawoto, 2013).

Tidak semua pertunjukkan rakyat bisa dikategorikan sebagai media tradisional yang bisa menyampaikan informasi kepada publik. Rusadi (2008) mengatakan bahwa media tradisional sebetulnya merupakan bagian dari pertunjukkan rakyat, yang membedakan media tradisional dengan pertunjukkan rakyat adalah kemampuannya menyebarluaskan informasi, seperti cerita rakyat, teater rakyat, nyanyian rakyat, wayang, ketoprak, dan sebagainya. Jadi sekalipun memiliki kesamaan dalam hal menghibur rakyat belum tentu semua pertunjukkan rakyat merupakan media tradisional (Rusadi, 2008).

Pertunjukkan Wayang Golek, Reog, Longser, Cigawiran, Tembang Sunda, Calung, dan Tarling merupakan kesenian tradisional dari Jawa Barat yang bisa dikategorikan ke dalam media tradisional. Pertunjukkan rakyat tersebut biasanya mengangkat cerita antara kebaikan dan keburukan, diselingi dengan humor-humor 
dan disisipkan informasi dari pemerintah yang mengajak masyarakat untuk menyukseskan program yang sedang digalakkan. Coseteng dan Nemenzo dalam Jahi (1988), mengatakan bahwa pertunjukkan rakyat, adalah bentuk penyampaian pesan verbal, gerakan, lisan, dan visual yang dikenal atau diakrabi rakyat, diterima oleh mereka, dan diperdengarkan atau dipertunjukkan oleh dan atau untuk mereka dengan maksud menghibur, memaklumkan, menjelaskan, mengajar, dan mendidik.

Seiring dengan perkembangan zaman satu persatu jenis pertunjukkan rakyat di Indonesia pada umumnya, dan Jawa Barat pada khususnya mulai berkurang jumlahnya bahkan ada yang punah. Kalaupun masih ada, perkembangannya cukup mengawatirkan, karena semakin ditinggalkan oleh penontonnya. Hilangnya sebagian pertunjukkan rakyat di tanah air khususnya di Jawa Barat berkaitan dengan semakin berkembangnya teknologi informasi dan komunikasi (TIK).

Perkembangan TIK tersebut menjadikan dunia seakan tanpa mengenal batas wilayah, manusia dapat mengakses informasi dan mendapatkan hiburan yang dibutuhkan setiap saat, dengan mudah, murah, dan cepat. Perkembangan tersebut juga telah mengantarkan masyarakat Indonesia pada sebuah perubahan yang berdampak signifikan terhadap seluruh kehidupan manusia. Implikasi dari hal tersebut terjadilah konvergensi (mengarah pada satu titik). Di mana manusia dapat menggunakan satu alat untuk berbagai keperluan, seperti untuk berkomunikasi, mencari dan mendapatkan informasi, mendengarkan radio, menonton televisi (Komisi Penyiaran Indonesia Pusat, 2013).

Perkembangan TIK juga telah memunculkan media baru dan menghasilkan alat yang canggih seperti televisi, handphone (HP) dengan berbagai fasilitasnya. Alat tersebut ternyata sangat digemari oleh masyarakat. Dengan harga yang cukup terjangkau dan berbagai kemudahan fasilitas yang diberikan membuat alat tersebut hampir dimiliki oleh semua orang.
Dampak yang dirasakan oleh grup-grup pertunjukkan rakyat berkaitan dengan perkembangan TIK, antara lain adalah apresiasi masyarakat terhadap pertunjukkan rakyat mulai bergeser, masyarakat saat ini cenderung menyukai budaya populer. Produkproduk pekembangan TIK seperti televisi, internet, media sosial, telah membawa budaya populer dikonsumsi oleh publik. Seperti dikatakan Rusadi (2008), bahwa ekspansi media televisi secara nasional dewasa ini telah menjauhkan apresiasi masyarakat terhadap media tradisional, khususnya di kalangan generasi muda. Mereka lebih mengenal penyanyi dan grup-grup musik populer ketimbang media tradisional di wilayahnya.

Meskipun demikian, masih ada beberapa grup calung yang saat ini masih tetap eksis, khusus di Kabupaten Garut, ada sebuah grup calung yang bernama Pitaloka yang tetap eksis di tengah perkembangan teknologi komunikasi dan informasi yang semakin berkembang pesat. Meskipun keberadaannya juga masih cukup mengawatirkan karena berbagai masalah yang dihadapinya, baik internal maupun eksternal. Keunikan pertunjukkan Calung Pitaloka di Kabupaten Garut adalah bahwa pertunjukkan tersebut merupakan warisan budaya, bisa dijadikan sebagai media komunikasi dan bisa menjadi media penyebar informasi atau diseminasi informasi ke masyarakat, di tengah-tengah perkembangan teknologi komunikasi dan informasi yang tengah melanda masyarakat Indonesia. Oleh karenanya keberadaan grup pertunjukkan Calung Pitaloka perlu dikembangkan agar di kemudian hari menjadi grup pertunjukkan rakyat yang bisa bersaing dengan grup-grup musik modern yang saat ini berkembang cukup pesat dengan menggunakan alat-alat canggih yang merupakan produk dari perkembangan teknologi komunikasi dan informasi.

Oleh karena itulah penulis tertarik untuk melakukan penelitian dengan judul "Pengembangan Pertunjukkan Calung sebagai Media Komunikasi di Era Konvergensi" Penelitian ini akan mengangkat permasalahan bagaimana pengembangan grup pertunjukkan 
calung Pitaloka sebagai media komunikasi di era konvergensi? dengan menggunakan analisis SWOT. Adapun identifikasi masalahnya adalah sebagai berikut: 1) Bagaimana kondisi grup pertunjukkan Calung Pitaloka dalam menghadapi era konvergensi saat ini? 2) Bagaimana kekuatan, kelemahan, peluang, dan ancaman grup pertunjukkan Calung Pitaloka sebagai media komunikasi di era konvergensi? 3) Bagaimana strategi pengembangan grup pertunjukkan Calung Pitaloka sebagai media komunikasi di era konvergensi? 4) Bagaimana formalisasi program untuk pengembangan grup pertunjukkan Calung Pitaloka sebagai media komunikasi di era konvergensi?

Adapun tujuan dari penelitian ini adalah ingin mengidentifikasi kondisi grup pertunjukkan Calung Pitaloka sebagai media komunikasi dalam menghadapi era konvergensi saat ini; Merumuskan strategi pengembangan grup pertunjukkan Calung Pitaloka sebagai media komunikasi di era konvergensi; Menganalisis kekuatan, kelemahan, peluang, dan ancaman pengembangan grup pertunjukkan Calung Pitaloka sebagai media komunikasi di era konvergensi; Merumuskan formalisasi program untuk pengembangan grup pertunjukkan Calung Pitaloka sebagai media komunikasi di era konvergensi. Sedangkan kegunaan dari penelitian ini adalah hasil penelitian ini diharapkan memberi masukan kepada: 1) Dirjen Komunikasi dan Informasi Publik (KIP) Kementerian Kominfo RI, untuk mengetahui sejauhmana keberadaan pertunjukkan rakyat khususnya calung, yang masih eksis dan memunyai potensi untuk dikembangkan sebagai media komunikasi publik; 2) Kelompok pertunjukkan rakyat yang ada di Provinsi Jawa Barat khususnya, untuk melakukan berbagai inovasi agar tidak tenggelam di tengah kemajuan TIK saat ini; 3) Pemerintah daerah khususnya Dinas Komunikasi dan Informatika, tentang bagaimana strategi yang harus dilakukan oleh grup pertunjukkan rakyat di era konvergensi.

Tidak semua jenis pertunjukkan rakyat dapat dijadikan sebagai media komunikasi, oleh karenanya dalam penelitian ini akan dipilih jenis pertunjukkan rakyat yang bisa dikategorikan sebagai media tradisional dan dapat dijadikan sebagai media komunikasi penyampai informasi dari pemerintah yakni pertunjukkan calung dengan mengambil kasus pada grup pertunjukkan Calung Pitaloka di Kabupaten Garut dengan menggunakan analisis SWOT.

\section{LANDASAN KONSEP}

\section{Penelitian Terdahulu}

Ada beberapa penelitian terdahulu mengenai pertunjukkan rakyat yang bisa dijadikan sebagai media komunikasi. Perbedaan dari beberapa penelitian tersebut dengan penelitian yang penulis susun saat ini terlihat pada tabel 1 .

Banyaknya penelitian yang telah dilakukan mengenai efektivitas pertunjukkan rakyat sebagai media komunikasi, menjadi pijakan bagi penulis untuk melakukan penelitian yang berbeda dengan penelitian terdahulu, baik dari sisi fokus penelitian, tujuan penelitian, pendekatan penelitian maupun dari sisi teknis pengumpulan datanya. Peneliti ingin menyoroti pengembangan pertunjukkan Calung Pitaloka, dengan menawarkan beberapa strategi pengembangannya dan menganalisisnya menggunakan analisis SWOT.

\section{Pengembangan Pertunjukkan Calung sebagai Media Komunikasi di Era Konvergensi}

Jika ditilik dari sejarahnya pertunjukkan rakyat di Indonesia bermula dari sebuah seni pertunjukkan dan baru ada sekitar satu setengah abad yang lalu. Berbagai bentuk seni pertunjukkan seperti sandiwara Dardanela, Opera Van Java, Ketoprak, Wayang Orang, baru dipakai sebagai pertunjukkan sekitar tahun 1900-an. Sebelum Proklamasi Kemerdekaan Indonesia, hampir semua seni pertunjukkan digunakan sebagai alat perjuangan, pengumpul massa, dan identitas masyarakat.

Setelah kemerdekaan Indonesia, seni pertunjukkan masih digunakan sebagai bagian alat politik sehingga muncul Lesbumi, Lembaga Kesenian Negara (LKN), dan 
sejenisnya. Baru setelah Orde Baru seni pertunjukkan rakyat digunakan sebagai media pemerintah untuk menyampaikan programnya (Suparno dalam Subandi, 2011).

Dissanayake dalam Melkote (1991) mendefinisikan media rakyat sebagai sebuah "Sistem komunikasi yang melekat dalam kebudayaan yang telah eksis sebelum media massa muncul, dan masih eksis sebagai media komunikasi yang vital di berbagai belahan dunia, menyajikan sebuah tingkat kelancaran tertentu, meski berubah" (Harun, 2011). Lebih lanjut dikatakan dalam Harun (2011), bahwa manfaat dari media rakyat diutamakan untuk kepentingan hiburan dan memersuasi khalayak atas pesan-pesan yang disampaikan.

Ranganath dalam Jahi (1988), menuturkan bahwa media tradisional itu

Tabel 1

Perbedaan Penelitian Pengembangan Pertunjukkan Calung Pitaloka di Era Konvergensi dengan Penelitian Terdahulu

\begin{tabular}{cl}
\hline & \multicolumn{1}{c}{$\begin{array}{c}\text { Kajian Efektivitas Seni } \\
\text { Karawitan sebagai Media } \\
\text { Pemasyarakatan Teknologi } \\
\text { Hama Terpadu (PHT) }\end{array}$} \\
\hline Penulis & \multicolumn{1}{c}{ Nani Tri Iswadayati } \\
\hline Peskripsi & $\begin{array}{l}\text { Media seni khususnya seni } \\
\text { tradisional yang berakar pada } \\
\text { kebudayaan lokal ditinjau dari } \\
\text { bahasanya, nilai-nilai, adat- } \\
\text { istiadat, dan lain-lain merupakan } \\
\text { salah satu pilihan sebagai media } \\
\text { komunikasi. Karawitan telah } \\
\text { dijadikan sebagai media } \\
\text { diseminasi informasi tentang } \\
\text { penggunaan teknologi baru di } \\
\text { bidang pertanian. }\end{array}$
\end{tabular}

Fokus Penelitian Penggunaan seni karawitan sebagai media penyebarluasan teknologi PHT bagi masyarakat perdesaan.

Tujuan Penelitian Mengkaji tingkat efektivitas media seni karawitan dalam menyebarluaskan teknologi PHT di masyarakat tani, dengan tujuan mempelajari faktor-faktor spesifik yang memengaruhi efektivitas media karawitan dan mempelajari efektivitas media ditinjau dari segi umur dan pendidikan petani.

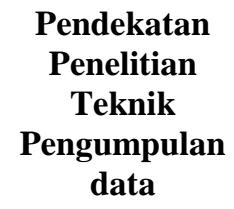

Teknik eksperimen

Kuesioner (angket) kepada para penonton karawitan yang sedang sebagai media komunikasi PHT

\section{Judul Penelitian}

Motif, Tujuan, dan

Manfaat Pertunjukkan

Wayang Orang Ngesti

Pandowo bagi

Penonton

Siti Sadiyah

Seni pertunjukkan

kesenian tradisional dari ritual menjadi tontonan komersial. Kesenian tradisional saat ini semakin sulit ditemui di kota-kota besar.

Motivasi, tujuan, dan manfaat penonton dalam menonton pertunjukkan wayang orang di Ngesti Pandowo

Mengungkap motif, tujuan, dan manfaat penonton dalam menonton pertunjukkan wayang orang di Ngesti Pandowo.

Kuantitatif berlangsung, secara acak.
. penonton wayang orang di Ngesti Pandowo dan juga wawancara mendalam.

Pengembangan
Pertunjukkan Calung
sebagai Media
Komunikasi di Era
Konvergensi
C.Suprapti Dwi
Takariani

Pertunjukkan rakyat merupakan media tradisional yang bisa dikategorikan sebagai media komunikasi dan berkembang pesat di Indonesia pada era tahun 70-an. Namun di era konvergensi, pertunjukkan rakyat mulai ditinggalkan penontonnya.

Pengembangan

pertunjukkan Calung dengan menggunakan analisis SWOT

Mengidentifikasi kondisi, menganalisis kekuatan, kelemahan, peluang, dan ancaman, merumuskan strategi, merumuskan saran untuk optimalisasi pengembangan pertunjukkan calung sebagai media komunikasi di era konvergensi.

\section{Kualitatif}

Wawancara mendalam dengan informan kunci dan informan pendukung dan observasi. 
akrab dengan massa khalayak, kaya akan variasi, dengan segera tersedia, dan biayanya rendah. Di samping itu, ia memiliki potensi yang besar bagi komunikasi persuasif, komunikasi tatap muka, dan umpan balik yang segera. Ranganath juga memercayai bahwa media tradisional dapat membawa pesan-pesan modern.

Ada beberapa tujuan penggunaan media rakyat (tradisional), yakni: membangun hubungan kedekatan, pengikat/perekat transaksi sosial, pengakuan/penghargaan identitas diri dan eksistensi budaya, penyeimbang dominasi media modern, dan menghilangkan pembatas sistem tradisional dan modern. Tema yang biasanya berkembang dalam media rakyat menyangkut ekspresi hidup, keteladanan, simbol-simbol, ritual, cita-cita budaya, dan nilai (baik dan buruk). Dalam tema tersebut disisipkan pesan-pesan atau informasi yang telah dititipkan. Di sini pertunjukkan rakyat berfungsi menuntun masyarakat untuk memahami batas baik dan buruk yang mesti dilakukan dan cara melakukannya. Melalui pertunjukkan rakyat segala ide, gagasan, atau inovasi pembangunan, diceritakan dan disesuaikan dengan bentuk media yang ada. Dengan demikian, ide pembangunan dan produk-produk kebudayaan lokal masyarakat dapat saling mengisi (Dilla, 2012).

Pertunjukkan calung merupakan salah satu pertunjukkan rakyat yang bisa dijadikan sebagai media komunikasi. Nama calung, memang masih terdengar asing bagi masyarakat Indonesia selain masyarakat Jawa Barat. Pertunjukkan calung belum banyak diketahui sebagai alat musik tradisional khas Sunda. Prototipe dari angklung ini memiliki harmoni yang enak didengar dan memiliki nilai historis yang tinggi (Raka, 2012).

Sebagai media komunikasi, pertunjukkan calung juga memiliki unsurunsur komunikasi, seperti komunikator, pesan, media, komunikan, dan efek. Lasswell dalam Effendy (2005), mengatakan bahwa cara yang baik untuk menjelaskan komunikasi ialah menjawab pertanyaan sebagai berikut: Who Says What in Which Channel To Whom With What Effect? Paradigma Lasswell di atas menunjukkan bahwa komunikasi meliputi lima unsur sebagai jawaban dari pertanyaan yang diajukan itu, yakni: komunikator (communicator, source, sender), pesan message), media (channel), komunikan (communicant, communicatee, receiver, recipient), efek (effect, impact, influence). Jadi berdasarkan paradigma Lasswell tersebut, komunikasi adalah proses penyampaian pesan oleh komunikator kepada komunikan melalui media yang menimbulkan efek tertentu. Melalui pertunjukkan calung pesan-pesan/informasi disampaikan oleh pemain calung (komunikator) kepada penonton (komunikan), dengan tujuan untuk mengubah sikap atau opini atau perilaku penontonnya.

Indonesia saat ini telah memasuki era konvergensi. Era di mana segala bentuk informasi akan diubah ke dalam format digital, sehingga dapat dikirim dalam satuan bit (binary digital). Format digital dari informasi yang dikirim tersebut akan menimbulkan konvergensi yang mengarah pada lahirnya produk-produk aplikatif yang mampu melakukan fungsi audio visual dan komputasi secara bersamaan (Komisi Penyiaran Indonesia Pusat, 2013). Secara harfiah, konvergensi dapat diartikan sebagai pertemuan dua hal yang berbeda pada satu titik (Yebambang, 2013).

Teknologi informasi baru yang bersifat konvergen sebagai akibat dari globalisasi dan digitalisasi menawarkan beberapa manfaat bagi masyarakat. Pada era tersebut, muncul media baru dan produk-produk yang selain menawarkan begitu banyak manfaat bagi masyarakat juga menawarkan kemudahankemudahan. Masyarakat bisa mengakses beragam informasi yang mereka butuhkan dengan cepat, mudah, dan murah.

Berkembangnya teknologi komunikasi dan informasi sedikit banyak ikut memengaruhi eksistensi pertunjukkan calung, karena semakin banyak budaya populer baik dari dalam negeri maupun dari luar negeri yang dengan mudah bisa masuk dan diakses oleh masyarakat terutama generasi mudanya.

Pengembangan pertunjukkan rakyat sebagai media komunikasi di era konvergensi perlu dilakukan, tujuannya adalah untuk memberikan keuntungan baik bagi 
pemerintah juga memberikan keuntungan bagi masyarakat luas. Karena secara tidak langsung media tradisional juga telah melestarikan kekayaan budaya bangsa dan meminimalkan masuknya budaya asing melalui berbagai media komunikasi massa modern yang tumbuh dan berkembang dengan pesat.

Pengembangan sendiri dapat diartikan sebagai suatu strategi yang digunakan untuk memajukan, memerbaiki, dan meningkatkan kondisi dan daya tarik suatu objek, sehingga dapat menarik penonton serta mampu memberikan manfaat bagi masyarakat di sekitar objek (Paturusi, 2001). Selanjutnya Suwantoro (1997) menyatakan bahwa pengembangan bertujuan untuk mengembangkan produk dan pelayanan yang berkualitas, seimbang, dan bertahap (Suwantoro,1997).

\section{METODE PENELITIAN}

Penelitian ini menggunakan metode kualitatif (qualitative approach) dengan pendekatan studi kasus. Pada penelitian ini kasus yang diteliti adalah pengembangan pertunjukkan calung sebagai media komunikasi di era konvergensi. Untuk menjawab dan memecahkan permasalahan yang telah dirumuskan, diperlukan model yang merupakan abstraksi dan sintesis dari kajian pustaka. Penelitian ini diawali dengan mengobservasi dan mencari tahu potensipotensi grup pertunjukkan Calung Pitaloka di Kabupaten Garut dan dicari juga faktor internal berupa kekuatan dan kelemahan, serta faktor eksternal berupa peluang dan ancaman. Kemudian dilanjutkan dengan menggunakan analisis SWOT secara kualitatif untuk merumuskan strategi alternatifnya. Analisis SWOT secara sederhana dipahami sebagai pengujian terhadap kekuatan dan kelemahan internal sebuah organisasi, serta kesempatan dan ancaman lingkungan eksternalnya (Johnson, dkk., Bartol, dkk, dalam Sulistiyo, 2008).
Salah satu model analisis SWOT yang merupakan rangkuman dari beberapa model adalah yang diperkenalkan oleh Kearns (1992). Berdasarkan uraian tersebut, maka dapat digambarkan kerangka konsep atau model penelitian pengembangan pertunjukkan calung Pitaloka sebagai media komunikasi di era konvergensi, dengan menggunakan model dari Kearns seperti terlihat pada tabel 2.

Dalam penelitian ini informan ditentukan dengan menggunakan teknik purposive sampling. Informan yang dipilih didasarkan atas pertimbangan:

1. Informan tercatat sebagai ketua atau salah satu anggota pertunjukkan rakyat.

2. Informan adalah pelaku dalam pertunjukkan rakyat.

3. Kesediaan informan untuk diwawancarai oleh penulis.

4. Kemampuan informan dalam memberikan informasi yang relevan dengan latar belakang penelitian.

Informan penelitian dapat dilihat pada tabel 3. Teknik pengumpulan data primer dilakukan melalui wawancara mendalam (depth interview) yaitu menggali informasi dari para informan dengan menggunakan panduan dan pedoman wawancara. Teknik pengumpulan data sekunder dilakukan melalui observasi yakni melakukan pengamatan terhadap keberadaan grup pertunjukkan Calung Pitaloka di Kabupaten Garut. Penggunaan dokumentasi dilakukan untuk mendukung kelengkapan data penelitian.

Data yang berhasil peneliti kumpulkan dari lapangan kemudian ditabulasi. Analisis data merupakan proses kegiatan pengolahan hasil penelitian, mulai dari menyusun, mengelompokkan dalam kategori sejenis, menelaah, dan menafsirkan data dalam pola serta hubungan antarkonsep dan merumuskannya dalam hubungan antara unsur-unsur lain agar mudah dimengerti dan dipahami. Teknik analisis data menggunakan analisis SWOT (Strength, Weakness, Opportunity, dan Threats). 
Tabel 2

Kerangka Konsep Penelitian

\begin{tabular}{|c|c|c|}
\hline $\begin{array}{l}\text { Faktor } \\
\text { Internal }\end{array}$ & $\begin{array}{c}\text { Peluang }(\mathrm{O}) \\
\text { grup pertunjukkan Calung } \\
\text { Pitaloka }\end{array}$ & $\begin{array}{c}\text { Ancaman }(\mathrm{T}) \\
\text { grup pertunjukkan Calung } \\
\text { Pitaloka }\end{array}$ \\
\hline $\begin{array}{c}\text { Kekuatan }(\mathrm{S}) \\
\text { grup pertunjukkan Calung } \\
\text { Pitaloka }\end{array}$ & $\begin{array}{c}\mathbf{S}-\mathbf{O} \\
\text { Strategi pengembangan }\end{array}$ & $\begin{array}{c}\mathbf{S}-\mathbf{T} \\
\text { Strategi pengembangan }\end{array}$ \\
\hline $\begin{array}{c}\text { Kelemahan }(\mathrm{W}) \\
\text { grup pertunjukkan Calung } \\
\text { Pitaloka }\end{array}$ & $\begin{array}{c}\mathbf{W}-\mathbf{O} \\
\text { Strategi pengembangan }\end{array}$ & $\begin{array}{c}\mathbf{W}-\mathbf{T} \\
\text { Strategi pengembangan }\end{array}$ \\
\hline
\end{tabular}

Tabel 3

Informan Penelitian

\begin{tabular}{cll}
\hline No & \multicolumn{1}{c}{ Nama Informan } & \multicolumn{1}{c}{ Jabatan } \\
\hline 1. & Enting Irawan RG & Ketua grup pertunjukkan Calung Pitaloka. \\
2. & Jajang & Anggota grup pertunjukkan Calung Pitaloka. \\
3. & Dede & Anggota grup pertunjukkan Calung Pitaloka. \\
4. & Dangdang & Anggota grup pertunjukkan Calung Pitaloka. \\
5. & Nunuy & Anggota grup pertunjukkan Calung Pitaloka. \\
6. & Awu & Anggota grup pertunjukkan Calung Pitaloka. \\
7. & Yayan Ahmadyani & Kasubag Publikasi dan Dokumentasi Bagian \\
& & Informatika Kabupaten Garut. \\
8. & Empit & Kasi Kesenian Disbudpar Kabupaten Garut. \\
\hline
\end{tabular}

Sumber : hasil penelitian.

\section{HASIL PENELITIAN DAN PEMBAHASAN}

\section{Kondisi Grup Pertunjukkan Calung Pitaloka di Era Konvergensi}

Grup pertunjukka Calung Pitaloka didirikan pada tahun 2005 oleh Kang Enting Irawan. Terdiri dari enam pemain inti dan beberapa pemain cadangan. Susunan dari pemain inti adalah dalang (Kang Enting) memegang calung 1, pemain calung 2 (Kang Dede), pemain calung 3 (Kang Awu), pemain calung 4 (Kang Dadang), pemain calung 5 (Kang Nunuy), dan pemain cadangan kang Jajang dan kang Agus Obar. Sekretariat grup pertunjukkan Calung Pitaloka di gedung Balai Paminton, jalan Ahmad Yani No. 30, Kota Garut.

Grup pertunjukkan Calung Pitaloka tidak hanya menyajikan lagu dan musik dalam setiap pertunjukkannya, namun juga menyajikan obrolan berupa lawakan yang isinya

menyampaikan pesan-pesan ke masyarakat. Motto dari grup pertunjukkan Calung Pitaloka adalah "Menghasilkan Suatu Pentas Yang Baik Adalah Latihan". Artinya adalah bahwa diperlukan latihan yang terus menerus dan kontinyu untuk menghasilkan sebuah pertunjukkan yang berkualitas, meskipun grup tersebut sudah beberapa kali mendapat penghargaan namun tetap perlu latihan secara kontinyu. Agar profesional grup pertunjukkan Calung Pitaloka Pitaloka didaftarkan sebagai Badan Hukum di Notaris pada tahun 2013.

Grup pertunjukkan Calung Pitaloka merupakan salah satu pertunjukkan rakyat yang saat ini masih tetap eksis. Di usianya yang terbilang masih muda yakni 9 tahun sejak didirikan pada tahun 2005, grup tersebut terus mengalami perkembangan meskipun tersendat-sendat, karena berbagai kendala. Grup tersebut terus berusaha untuk 
memperkenalkan diri ke masyarakat untuk melakukan pertunjukkan meskipun kadangkadang tidak mendapatkan bayaran.

Grup pertunjukkan Calung Pitaloka saat ini bisa diterima oleh masyarakat di Kabupaten Garut meskipun masih dari kalangan terbatas dan di tengah perkembangan teknologi komunikasi dan informasi yang semakin berkembang pesat serta munculnya grup-grup band dengan musik metal yang saat ini secara rutin mengadakan pentas di Kabupaten Garut. Menurut Ibnu Hamad dalam Rusadi (2008), ada sepuluh potensi komunikasi melalui pertunjukkan rakyat yang dinilai cukup efektif yakni: 1) Mampu menyampaikan pesan dalam berbagai cara sekaligus yaitu ucapan, gerakan, kata-kata, dan gambar; 2) Diakrabi oleh khalayak sehingga ia memiliki sosio kultural dengan penonton; 3) Dapat dilakukan dialog antara pemain dengan penonton; 4) Bukan hanya menyampaikan pesan tetapi juga menghibur; 5) Pesan bisa diurai, dirinci, diulas sehingga memperjelas pesan yang akan disampaikan; 6) Menyampaikan pesan pendidikan dan nilainilai kebaikan; 7) Dapat memberikan arahan yang harus dilakukan dan yang tidak boleh dilakukan; 8) Dapat disisipkan banyak pesan sehingga efektif sebagai saluran komunikasi; 9) Dapat menyesuaikan dengan konteks situasi dan kondisi pada saat pertunjukkan berlangsung; 10) Dapat diperluas jangkauannya melalui media televisi dan radio.

Pimpinan grup pertunjukkan Calung Pitaloka terus berusaha mengembangkan grup tersebut dengan melakukan koordinasi dengan instansi pemerintah yang terkait dengan kesenian daerah, mengikuti berbagai festival/seminar/bimtek. Melakukan latihan secara rutin agar performance mereka lebih bagus dan mampu menarik penonton. Melakukan evaluasi apa saja kekurangan grup tersebut ketika pentas. Semuanya dilakukan agar grup tersebut mendapat dukungan dari pemerintah maupun swasta.

Meskipun demikian grup pertunjukkan Calung Pitaloka juga tidak terlepas dari berbagai hambatan maupun tantangan yang datang dari luar. Hambatannya seperti terbatasnya anggaran, terbatasnya sarana maupun prasarana, terbatasnya SDM, perkembangan TIK yang sudah tidak terbendung lagi, maraknya grup musik organ tunggal, grup-grup musik punk rock yang telah berhasil merebut simpati remaja sehingga grup tersebut bisa melakukan pentas secara rutin di Kabupaten Garut.

Kekuatan, Kelemahan, Peluang, dan Ancaman Grup Pertunjukkan Calung Pitaloka sebagai Media Komunikasi di Era Konvergensi

Berdasarkan kondisi grup pertunjukkan Calung Pitaloka saat ini, maka diketahui beberapa kekuatan dan kelemahan serta peluang dan ancaman yang dimiliki oleh grup pertunjukkan Calung Pitaloka di Kabupaten Garut. Selanjutnya dapat dianalisis isu strategis yang dihadapi oleh grup pertunjukkan Calung Pitaloka di Kabupaten Garut. Dari isu-isu strategis tersebut dapat dikembangkan isu-isu kombinasi yang saling berpengaruh, sebagai berikut:

1. Strategi SO

Strategi ini dibuat berdasarkan lembaga, yakni dengan memanfaatkan seluruh kekuatan untuk merebut dan memanfaatkan peluang sebesar-besarnya.

S1-O1: bagaimana memanfaatkan motivasi pimpinan dan kemampuan para pemain calung untuk menarik dukungan pemerintah daerah dalam menunjang kegiatan grup pertunjukkan Calung Pitaloka.

S2-O2: bagaimana memanfaatkan fasilitas yang tersedia berupa ruang, peralatan, kostum, untuk meningkatkan kualitas pertunjukkan sehingga semakin banyak mendapatkan tawaran/undangan untuk pentas, tidak hanya dari sekolah dan instansi pemerintah saja.

S3-O3: bagaimana pimpinan dan juga anggota grup pertunjukkan Calung Pitaloka dapat mencari metode pengembangan seni calung yang sesuai dengan keinginan/kebutuhan masyarakat saat ini, untuk mendapatkan kesempatan mengisi acara tidak di televisi lokal namun juga bisa menembus televisi nasional.

S4-O4: Bagaimana memanfaatkan kekuatan dalam menyampaikan pesan melalui 
pertunjukkan calung, untuk menarik simpati dari penonton kalangan remaja melalui sekolah-sekolah/perguruan tinggi.

2. Strategi ST

Ini adalah strategi dalam menggunakan kekuatan yang dimiliki perusahaan untuk mengatasi dan menghindari ancaman.

S1-T1: Bagaimana memanfaatkan motivasi pimpinan dan kemampuan para pemain grup pertunjukkan Calung Pitaloka dengan menyuguhkan pertunjukkan yang lebih baik dan diterima juga oleh kalangan remaja untuk mengimbangi munculnya grup musik punk rock atau grup-grup musik yang menyajikan musik dari negara lain.

S2-T2: Bagaimana meningkatkan atau mengembangkan fasilitas yang telah dimiliki untuk dapat mengimbangi perkembangan teknologi komunikasi dan informasi yang semakin berkembang.

S3-T3: Bagaimana pimpinan grup pertunjukkan Calung Pitaloka dapat mengembangkan pertunjukkan calung dengan alat musik lain untuk mengimbangi maraknya alat musik organ/organ tunggal.

S4-T4: Bagaimana meningkatkan penyampaian pesan-pesan seefektif mungkin untuk mengimbangi perkembangan TIK, organ tunggal, maupun grup musik punk rock.

3. Strategi WO

Ini adalah strategi dalam menyikapi dan mengurangi kelemahan dengan memanfaatkan peluang yang ada.

W1-O1: Bagaimana mendapatkan cara dalam memeroleh dukungan dari pemerintah untuk mengatasi masalah anggaran yang belum memadai.

W2-O2: Bagaimana memanfaatkan undangan dari instansi pemerintah dengan melakukan evaluasi setelah melakukan berbagai pertunjukkan untuk perbaikan selanjutnya.

W3-O3: Bagaimana memanfaatkan dukungan anggaran dari pemerintah daerah untuk menambah alat-alat musik yang mengikuti selera penonton dan mengganti alat-alat musik yang sudah usang.

W4-O4: Bagaimana memanfaatkan dukungan dari pemerintah daerah dengan mengelola grup pertunjukkan Calung Pitaloka secara profesional.

\section{Strategi WT}

Ini adalah strategi dalam menyikapi dan mengurangi kelemahan yang ada guna menghindari potensi ancaman yang ada.

W1-T1: Bagaimana meningkatkan anggaran untuk bisa melakukan pentas lebih sering dan mengimbangi pementasan grup musik punk rock dan grup-grup musik yang menyajikan musik dari negara lain yang sudah terjadwal dengan tetap.

W2-T3: Bagaimana melakukan regenerasi pemain untuk dapat mengimbangi perkembangan teknologi komunikasi dan informasi.

W3-T2: Bagaimana mencari cara untuk mengganti atau menambah peralatan musik calung untuk dapat mengimbangi perkembangan grup organ tunggal yang semakin marak saat ini.

W4-T4: Bagaimana mencari cara untuk mengelola organisasi secara profesional untuk mengimbangi maraknya grup-grup musik yang beraliran Barat.

\section{Strategi Pengembangan Grup Pertunjukkan Calung Pitaloka sebagai Media Komunikasi di Era Konvergensi}

Formulasi strategi yang ditawarkan dalam perencanaan strategis ini adalah strategi kombinasi isu-isu internal dan isu-isu eksternal yang digambarkan dalam tabel 5 .

\section{Formalisasi \\ Program untuk Pengembangan Grup Pertunjukkan Calung Pitaloka sebagai Media Komunikasi di Era Konvergensi}

Susunan program atau formulasi program untuk grup pertunjukkan Calung Pitaloka Kabupaten Garut, dapat ditawarkan sebagai berikut:

1. Pengembangan Sumber Daya Manusia

- Mengikutsertakan pemain grup pertunjukkan Calung Pitaloka dalam berbagai seminar dan workshop.

- Mengikutsertakan grup pertunjukkan Calung Pitaloka ke berbagai ajang festival calung baik tingkat regional maupun nasional secara rutin/kontinyu. 
- Melakukan studi banding ke berbagai daerah dengan fasilitas dari pemerintah daerah setempat.

- Menambah intensitas latihan agar lebih bagus dalam melakukan pertunjukkan.

- Menambah wawasan para pemainnya untuk menemukan tema-tema yang menarik dan mengikuti perkembangan TIK.

2. Pengembangan Organisasi

- Menjalin kerjasama ke berbagai pihak (Sekolah/Perguruan Tinggi, Swasta, pengelola televisi baik lokal maupun nasional) tidak hanya terbatas instansi pemerintah saja.

- Meningkatkan komunikasi yang baik dan selalu berkoordinasi dengan instansi pembina dan penyandang dana.

- Memelihara iklim budaya organisasi yang lebih demokratis.

- Mengelola organisasi secara profesional.

- Memanfaatkan teknologi komunikasi dan informasi untuk setiap pementasan/pertunjukkan.

\section{Tabel 4}

\section{Matrik SWOT Grup Pertunjukkan Calung Pitaloka Kabupaten Garut}

\begin{tabular}{|c|c|c|}
\hline $\begin{array}{l}\text { Faktor Eksternal } \\
\text { Grup pertunjukkan Calung } \\
\text { Pitaloka } \\
\text { Gaktor Internal pertunjukkan } \\
\text { Calung } \\
\text { Pitaloka }\end{array}$ & $\begin{array}{l}\text { Peluang }(\mathrm{O}) \\
\text { - Dukungan dari pemerintah } \\
\text { (Dinas Pariwisata dan Setda } \\
\text { Bag.Informatika } \\
\text { Kab.Garut). } \\
\text { - Undangan untuk pentas dari } \\
\text { instansi pemerintah. } \\
\text { - Undangan untuk pentas dari } \\
\text { sekolah. } \\
\text { - Undangan pentas dari } \\
\text { perseorangan (terbatas) }\end{array}$ & $\begin{array}{l}\text { Ancaman }(\mathrm{T}) \\
\text { - Munculnya grup musik punk } \\
\text { rock dan grup-grup musik } \\
\text { yang menyajikan musik dari } \\
\text { negara lain. } \\
\text { - Perkembangan teknologi } \\
\text { komunikasi \& informasi. } \\
\text { - Maraknya alat musik organ } \\
\text { tunggal. }\end{array}$ \\
\hline \begin{tabular}{l}
\multicolumn{2}{c}{ Kekuatan (S) } \\
- Motivasi pimpinan dan \\
kemampuan Sumber Daya \\
Manusia pemain calung yg \\
memenuhi kriteria (bisa bermain \\
musik \& melawak). \\
- Fasilitas ruang untuk latihan, \\
alat musik calung, kostum. \\
- Pesan-pesan yang disampaikan \\
cukup efektif, terutama karena \\
grup tersebut lebih sering \\
menggunakan bahasa Sunda.
\end{tabular} & $\mathbf{S}-\mathbf{O}$ & $\mathbf{S}-\mathbf{T}$ \\
\hline $\begin{array}{l}\text { Kelemahan (W) } \\
\text { - Anggaran yang belum memadai. } \\
\text { - Regenerasi pemain yang } \\
\text { lamban. } \\
\text { - Perlatan calung yang sudah } \\
\text { lama/tua. } \\
\text { - Pengelolaan/manajemen } \\
\text { organisasi belum dilakukan } \\
\text { secara profesional. } \\
\text { - Evaluasi keseluruhan setelah } \\
\text { pertunjukkan. }\end{array}$ & $W-O$ & $\mathbf{W}-\mathbf{T}$ \\
\hline
\end{tabular}

Sumber: Hasil penelitian tahun 2014. 


\section{Tabel 5}

\section{Matrik Strategi Kombinasi Internal-Eksternal}

\begin{tabular}{|c|c|c|}
\hline Faktor Eksternal & Peluang (O) & Ancaman (T) \\
\hline $\begin{array}{l}\text { Grup pertunjukkan } \\
\text { Calung } \\
\text { Pitaloka }\end{array}$ & $\begin{array}{l}\text { - Dukungan dari pemerintah (Disbudpar } \\
\text { dan Setda Bag.Informatika). } \\
\text { - Undangan untuk pentas dari instansi dan } \\
\text { sekolah. } \\
\text { - Dukungan anggaran dari instansi } \\
\text { (Disbudpar). }\end{array}$ & $\begin{array}{l}\text { - Munculnya grup musik punk rock } \\
\text { dan grup-grup musik yang } \\
\text { menyajikan musik dari negara lain. } \\
\text { - Perkembangan teknologi komunikasi } \\
\text { \& informasi. } \\
\text { - Maraknya alat musik organ tunggal. }\end{array}$ \\
\hline $\begin{array}{l}\text { Faktor Internal } \\
\text { Grup pertunjukkan Calung } \\
\text { Pitaloka }\end{array}$ & & \\
\hline
\end{tabular}

Kekuatan (S) S - O

- Motivasi pimpinan

kemampuan sumber daya • Memanfaatkan fasilitas yang ada manusia pemain calung yg seoptimal mungkin.

memenuhi kriteria (bisa - Merekrut anggota-anggota baru untuk bermain musik \& melawak).

- Fasilitas ruang untuk latihan, alat musik calung, kostum.

- Pengembangan seni calung yang bervariasi.

- Pesan-pesan yang disampaikan cukup efektif.

\section{regenerasi.}

- Menggunakan metode pertunjukkan yang baru, seperti tema yang disesuaikan dengan kondisi saat ini, menambah peralatan baru.

- Mengikutkan pimpinan atau anggota grup Calung Pitaloka ke berbagai festifal calung baik tingkat daerah maupun nasional.

- Mengikutkan pimpinan atau anggota grup Calung Pitaloka ke seminarseminar/pelatihan-pelatihan.

- Melakukan studi banding ke daerah lain.

- Meningkatkan dukungan dari pemerintah untuk mengembangkan fasilitas yang ada.
Strategi:

$$
\mathbf{S}-\mathbf{T}
$$

- Memanfaatkan motivasi pimpinan dan kemampuan anggota untuk lebih mengembangkan diri dan menambah wawasan mengenai TIK.

- Memanfaatkan fasilitas yang ada seoptimal mungkin.

- Memanfaatkan teknologi komunikasi dan informasi untuk mengembangkan calung.

- Memanfaatkan pesan-pesan yang cukup efektif diterima oleh penonton dengan mengembangkan tema-tema yang lebih menarik dan sedang tren di masyarakat.

\section{Kelemahan (W)}

- Anggaran yang memadai.

- Regenerasi pemain.

- Regenerasi peralatan music

- Pengelolaan belum secara profesional.

- Evaluasi keseluruhan setelah pertunjukkan.

\section{$\mathbf{W}-\mathbf{O}$}

- Meningkatkan dukungan pemda untuk menambah anggaran.

- Meningkatkan dukungan dengan berbagai pihak untuk menambah fasilitas khususnya penambahan peralatan yang sudah mulai usang dan menambah peralatan baru untuk mengimbangi maraknya grup musik.

- Meningkatkan intensitas pentas ke berbagai sekolah untuk menambah kecintaan terhadap seni calung dan sekaligus melakukan regenerasi pemain.

$$
\mathbf{W}-\mathbf{T}
$$

Strategi:

Meningkatkan kerjasama dengan baik dan menjalin hubungan yang baik dengan instansi pembina, seperti Setda Kabupaten Garut dan Disbudpar Kabupaten Garut khususnya, dan dengan instansi pembina tingkat Provinsi Jawa Barat yakni Diskominfo Provinsi.

- Menambah alat musik selain calung untuk mengimbangi maraknya organ tunggal.

- Melakukan regenerasi pemain, dengan merekrut pemain-pemain muda agar lebih bervariasi dan terjadi penyegaran di grup pertunjukkan Calung Pitaloka

Sumber: hasil penelitian tahun 2014.

3. Pengembangan Sarana dan Prasarana

- Memelihara kondisi peralatan calung yang sudah ada.

- Memelihara kostum yang sudah ada.
- Melengkapi peralatan calung agar bisa menyesuaikan diri dengan perkembangan teknologi komunikasi dan informasi.

- Menambah peralatan calung.

- Menambah peralatan sound system. 


\section{PENUTUP}

\section{Simpulan}

Grup pertunjukkan Calung Pitaloka di Kabupaten Garut saat ini dalam kondisi yang cukup menggembirakan dengan mulai dikenalnya grup tersebut serta undangan untuk pentas, setelah terpuruk akibat ditinggalkan oleh penontonnya.

Grup pertunjukkan Calung Pitaloka di Kabupaten Garut saat ini memiliki lebih banyak kelemahan dibanding dengan kekuatannya, namun demikian grup tersebut juga mempunyai peluang yang lebih banyak dibanding dengan acamannya, hal ini menjadi potensi bagi grup tersebut untuk mengembangkan dirinya.

Dengan kondisi tersebut strategi yang disusun adalah dengan memanfaatkan kekuatan dari dalam dan peluang yang ada untuk meminimalkan kelemahan dan ancaman yang akan datang dari luar, yakni dengan memanfaatkan berbagai fasilitas yang dimiliki dan memanfaatkan dukungan dari berbagai pihak, khususnya instansi pemerintah sebagai pembina dan menjalin hubungan yang lebih baik dengan berbagai pihak.

Formulasi pengembangan untuk grup pertunjukkan Calung Pitaloka di Kabupaten Garut disusun ke dalam tiga bidang yakni pengembangan sumber daya manusia, bidang pengembangan organisasi, dan bidang pengembangan sarana dan prasarana.

\section{Saran}

Kemenkominfo sebagai pembina media tradisional di tingkat pusat perlu untuk mengupayakan pengembangan media tradisional agar tetap eksis di era konvergensi saat ini, yakni dengan memantau perkembangan media tradisional yang ada di seluruh daerah khususnya di Kabupaten Garut dan melakukan upaya-upaya konkrit dengan mengeluarkan regulasi yang mendukung pengembangan media tradisional.

Bagi grup pertunjukkan rakyat khususnya calung, diharapkan untuk melakukan upaya-upaya dengan jalan menjalin hubungan dan berkoordinasi dengan berbagai pihak seperti instansi pemerintah, perguruan tingga, media lokal yang ada di daerah, agar tetap eksis di tengah perkembangan teknolgi komunikasi dan informasi.

Bagi pemerintah daerah, terutama instansi pembina grup pertunjukkan rakyat, perlu terus membina grup-grup yang masih hidup dan bertahan, dengan memberikan bantuan berupa anggaran, dan juga memberikan pelatihan/bimtek/seminar/studi banding agar grup-grup pertunjukkan rakyat dapat mengembangkan diri dan melakukan inovasi-inovasi untuk mengimbangi masuknya budaya Barat melalui teknologi komunikasi dan informasi.

\section{DAFTAR PUSTAKA}

Buku:

Amri, Jahi. (1988). Komunikasi Massa dan Pembangunan Pedesaan di NegaraNegara Dunia Ketiga. Jakarta: PT Gramedia.

Dilla, Sumadi. (2012). Komunikasi Pembangunan. Bandung: Simbiosa.

Effendy, Onong Uchjana. (2005). Ilmu Komunikasi Teori dan Praktek. Bandung: PT Remaja Rosdakarya.

Harun, H. Rochajat dan Elvinaro Ardianto. (2011). Komunikasi Pembangunan Perubahan Sosial Perspektif Dominan, Kaji Ulang, dan Teori Kritis. Jakarta: PT RajaGrafindo Persada.

Komisi Penyiaran Indonesia Pusat. (2013). Kedaulatan Frekuensi Regulasi Penyiaran, Peran KPI, dan Konvergensi Media. Ed. Wahyu Wibowo. Jakarta: PT Kompas Media Nusantara.

Mantra, Ida Bagoes. (2000). Filsafat Penelitian dan Metode Penelitian Sosial. Yogyakarta: Averroes Press.

Melkote, Srinivas R. (1991). Communication for Development in Third World. New Delhi: Sage Publication.

Mulyana, Deddy. (2004). Metodologi Penelitian Kualitatif. Bandung: PT Remaja Rosdakarya.

Salusu, J. (2003). Pengambilan Keputusan Stratejik Untuk Organisasi Publik dan 
Organisasi Nonprofit. Jakarta: PT Grasindo.

\section{Jurnal:}

Subandi. (2011). Deskripsi Kualitatif Sebagai Satu Metode. Jurnal HARMONIA. Volume 11 No.2/Desember 2011, hal 175.

Iswardayati, Nani Tri. (2006). Efektivitas Seni Karawitan sebagai Media Pemasyarakatan Teknologi Pengendalian Hama Terpadu (PHT) Studi Kasus di Desa Mula, Kecamatan Wonosari, Gunung Kidul. Jurnal Ilmu Pertanian. Volume 2 No. 2/Desember 2006, hal 112.

Kadri. (2011). Optimalisasi Peran Kesenian Tradisional NTB sebagai Media Komunikasi dan Pendidikan Sosial. Jurnal Aksa Sriti, Edisi 7 / Juni 2011, hal.27.

Sadiyah, Siti. (2013). Motif, Tujuan, dan Manfaat Pertunjukkan Wayang Orang Ngesti Pandowo bagi Penonton. Tersedia dalam http://ejournals1.undip.ac.id/index.php/sulukindo/artic le/view/2366/2367, diakses tanggal 1 Maret 2014.hal. 1-15.

\section{Tesis:}

Sulistyo, Fajar. (2008). Manajemen Sistem Monitoring dalam Rangka Penertiban dan Pengaturan Frekuensi Radio Nasional. Tesis. Universitas Indonesia.
Makalah:

Rusadi, Udi. (2008). Revitalisasi Media Tradisional dalam Penguatan Komunikasi Sosial di Indonesia. Disampaikan dalam Simposium Internasional Antropologi, 22 Juli 2008 di Banjarmasin.

Suprawoto. (2013). Dialog Interaktif "Pertunjukan Rakyat: Pendidikan dan Budaya Antikorupsi". Disampaikan dalam acara Pekan Informasi Nasional, 27 Mei 2013 di Medan.

\section{Surat Kabar:}

Raka. (2012). Calung Riwayatmu Kini. Radar Karawang. 25 September, hal. 3.

\section{Internet:}

Suwantoro. (1997). Strategi dan Program Pengembangan Pariwisata Desa Palaga Kabupaten Bandung. Tersedia dalam http://www.pps.unud.ac.id/thesis/pdf_th esis/unud-195-1729198672-

bab\%20ii.pdf. Diakses tanggal 1 Maret 2014.

Triyono, YeBambang. (2013). Konvergensi Media di Era Teknologi Digital. Tersedia dalam http://elearningrri.net/english/konvergensi-media-diera-teknologi-digital-yebambangtriyono. Diakses tanggal 20 Februari 2014. 